Vol. 3, No. 1, 2020

\author{
M. A. Sozanskyi, V. E. Stadnik, P. Yo. Shapoval, \\ O. P. Kurylo, R. R. Guminilovych \\ Lviv Polytechnic National University, \\ Department of Physical, Analytical and General Chemistry \\ martyn.a.sozanskyi@lpnu.com
}

\title{
QUANTUM-CHEMICAL MODELING OF THE CHEMISTRY PROCESS OF THE ZINC SULFIDE AND ZINC SELENIDE FILMS SYNTHESIS
}

https://doi.org/

The quantum-chemical modeling of the synthesis process chemistry of $\mathrm{ZnS}$ and $\mathrm{ZnSe}$ in aqueos solutions was carried out.For modeling the simulation of $\mathrm{ZnS}$ synthesis was made through the formation of $\mathrm{Zn}$ (II) complex forms with the trisodium citrate, sodium hydroxide and the pair of ammonium hydroxide with hydrazine hydrate. For the synthesis of $\mathrm{ZnSe}$ was used only sodium hydroxide.It was established that this process passes through several intermediate stages with the transitional reactive complexes formation. On the basis of obtained data, the energy stages diagrams are constructed and the comparison of $\mathrm{ZnS}$ and $\mathrm{ZnSe}$ synthesis processes with various complexing agents is presented.The $\mathrm{ZnS}$ and $\mathrm{ZnSe}$ filmswere obtained by chemical synthesis method from an aqueous solution of zinc salt, complexing and chalcogenizing agents. $X$-ray phase analysis confirmed the formation of desired compounds, as well as the formation of $\mathrm{ZnO}$ in the case of ammonium hydroxide - hydrazine hydrate usage at the synthesis of $\mathrm{ZnS}$ films.

Key words: zinc sulfide, zinc selenide, thin films, quantum-chemical modeling, semiempirical methods, semiconductors.

\section{Introduction}

Semi-empirical method of quantum chemistry is one of the modeling reactions methods between molecules and substances by quantum-chemical calculations [1-3]. In Refs. [4-6], the theoretical basis of metal sulfides films formation from aqueous solution were described. Among the main factors affecting the course of the reaction, the following can be distinguished:

1. Concentration of initial reagents of the solution from which depositionismade and the physical parameters of the process (temperature, synthesis duration, etc.);

2. Nature of complexing and chalcogenizing reagents that surround the metal ion and generate chalcogen ions during the synthesis, respectively;

3. Nature of the substrate surface on which the films are formed.

It was noted [4] that during the synthesis process, the formation of transitional molecular reactive complexes (TMRC), associates, cluster and colloidal forms were possible in the working solution due to cooperation and fluctuation phenomena, which occur between the liquid and solid phases (newly formed the reaction product and substrate) at a short distance from the latter.

For the some metals ions $\left(\mathrm{Me}=\mathrm{Pb}^{2+}, \mathrm{Cu}^{2+}\right.$, $\left.\mathrm{Cd}^{2+}, \mathrm{Hg}^{2+}\right)$, the formation of complexes with thiourea of $\left[\mathrm{Me}\left(\left(\mathrm{NH}_{2}\right)_{2} \mathrm{CS}\right)_{4}\right]^{2+}$ type was established $[4,7]$. From the reference data [4], the value of the stability constant of such zinc complex is very small (often absent in reference books), which does not apply to the mentioned above metals. So it is logical to assume the formation of intermediate complexes of $\left[\mathrm{L}_{\mathrm{n}} \cdots \mathrm{Zn} \cdots\left(\mathrm{NH}_{2}\right)_{2} \mathrm{CS}\right]$ type, where zinc is coordinated on the one hand by ligands of the complexing agent, and on the other by thiourea. The decomposition process of such intermediate complexes, as a rule, involves the formation of molecular forms, and then monomolecular layers of zinc chalcogenide. To reduce the formation of by-products, it is necessary to create conditions in which the supply of zinc- and chalcogen-containing agents will be the same. It is also worth noting that some complexing agents perform only one function - the formation of a complex with metal. In this case, it is 


\section{Quantum-chemical modeling of the chemistry process of the zinc sulfide and zinc selenide films synthesis}

necessary to add an additional $\mathrm{pH}$ regulator to ensure the stability and reactivity of the complex. Other complexing agents are able tofulfill two functions at the same time - to coordinate the metal ion and create the required hydrogen index of the solution.

\section{Aim of the work}

The aims of the present study are the following: 1. Implementationofquantum-chemical modeling of the $\mathrm{ZnS}$ and $\mathrm{ZnSe}$ synthesis processes withtheuseof PM7 method in MOPAC 2012 software package. This could be made on the basis of the hypothesis about the possibility of formation of transient reactive complexes, associates, clusters, structures of colloidal nature, which are structural units during the synthesis of zinc chalcogenide films due to the effects of co-operation and fluctuation in the working solution. 2. Comparison of the obtained results of $\mathrm{ZnS}$ and $\mathrm{ZnSe}$ simulations with the investigated properties of respective films. 3. Feasibility and efficiency evaluation of the synthesis in observed systems.

\section{Materials and research methods}

Modeling and calculations of the system energy change $(\Delta E)$ for the synthesis stages of zinc sulfide and zinc selenide were carried out by the semi-empirical method PM7 [8] with the use of MOPAC 2012 software package [9] and the Winmostar graphical interface [10].

The synthesis of $\mathrm{ZnS}$ films was carried out from a working solution prepared by mixing aqueous solutions of zinc chloride $\left(\mathrm{ZnCl}_{2}\right)$, complexing agent, thiourea $\left(\left(\mathrm{NH}_{2}\right)_{2} \mathrm{CS}\right)$ and, if necessary, the $\mathrm{pH}$ regulator. Solutions of trisodium citrate $\left(\mathrm{Na}_{3} \mathrm{C}_{6} \mathrm{H}_{5} \mathrm{O}_{7}\right)$, sodium hydroxide $(\mathrm{NaOH})$, and a pair of ammonium hydroxide $\left(\mathrm{NH}_{4} \mathrm{OH}\right)$ with hydrazine hydrate $\left(\mathrm{N}_{2} \mathrm{H}_{4} \cdot \mathrm{H}_{2} \mathrm{O}\right)$ were used as complexing agents. The exact synthesis parameters of $\mathrm{ZnS}$ films are given in ref. [11].

The synthesis of ZnSe films was carried out from a working solution prepared by mixing aqueous solutions of zinc chloride $\left(\mathrm{ZnCl}_{2}\right)$, sodium hydroxide and elemental selenium (Se) dissolved therein with the presence of hydrazine hydrate. The exact synthesis parameters of $\mathrm{ZnS}$ films are given in ref. [12, 13].

The X-ray diffraction patterns of deposited $\mathrm{ZnS}$ and $\mathrm{ZnSe}$ films samples were performedwith the

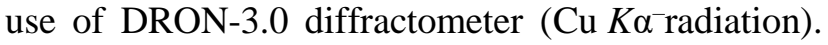
The primary treatment of films diffractogram for the identification of phases was carried outby using Powder Cell program [14].

\section{Results and discussion}

The results of quantum chemical modeling of the $\mathrm{ZnS}$ and $\mathrm{ZnSe}$ films synthesis chemistry in aqueous solutions with various complexing agents by semi-empirical methods are presented in table 1 . The geometry of starting zinc complexes are illustratedin Fig. 1-3.

Quantum-chemicalmodelingof $\mathrm{ZnS}$ synthesis chemistry with $\mathrm{Na}_{3} \mathrm{C}_{6} \mathrm{H}_{5} \mathrm{O}_{7}$.

Initially, when mixing solutions of zinc salt and trisodium citrate, a soluble $\left[\mathrm{Zn}\left(\mathrm{C}_{6} \mathrm{H}_{5} \mathrm{O}_{7}\right)\right]^{-}$ complex is formed (Fig. 1), where citrate ion plays the role of a ligand.

As can be seen from the conducted quantumchemical modeling(table. 1, no. 1, stages 1-3) that after adding thiourea and a small amount of $\mathrm{pH}$ regulator to the solution, the $\left[\left(\mathrm{NH}_{2}\right)_{2} \mathrm{CS} \cdots \mathrm{Zn}(\mathrm{OH})_{2}\left(\mathrm{C}_{6} \mathrm{H}_{5} \mathrm{O}_{7}\right)\right]^{3-}$ TMRC is formed in the early stages of deposition. In the TMRC the $\mathrm{Zn}$ atom is coordinated with the $\mathrm{S}$ atom (Fig. 4). This process is accompanied by a slight endoeffect, that is, energy absorption.

Next, starting from stage 3 to stage 6 , the formed complex undergoes rearrangement of two hydrogen atoms of $\left(\mathrm{NH}_{2}\right)_{2} \mathrm{CS}$ with two hydroxyl groups and detaching of two water molecules. As a result, $\left[\left(\mathrm{N}_{2} \mathrm{H}_{2} \mathrm{CS} \cdots \mathrm{Zn}\left(\mathrm{C}_{6} \mathrm{H}_{5} \mathrm{O}_{7}\right)\right]^{3-}\right.$ TMRC is formed. The result of these stages is a decrease in total energy of the system.

At the last stage, which is the most energyintensive, the newly formed intermediate complex decomposed with the formation of zinc sulfide, citrate ion and cyanamide (stages 6-7).

During deposition process, the citrate ion $\left(\mathrm{C}_{6} \mathrm{H}_{5} \mathrm{O}_{7}{ }^{3-}\right)$ does not change its structure and performs only a ligand role.

Quantum-chemicalmodelingof $\mathrm{ZnS}$ synthesis chemistry with $\mathrm{NaOH}$.

In the case of mixing of a zinc salt solution with an excess of sodium hydroxide solution, which is a complexing agent and $\mathrm{pH}$ regulator at the same time, a soluble complex of tetratrahydroxozincate $\left(\left[\mathrm{Zn}(\mathrm{OH})_{4}\right]^{2-}\right)$ is formed (Fig. 2).

As can be seen from the performed modeling (table 1, no. 2, stages 1-2) that TMRC $\left[\left(\mathrm{NH}_{2}\right)_{2} \mathrm{CS} \cdots \mathrm{Zn}(\mathrm{OH})_{4}\right]^{2-}$ is formed at the beginning of the deposition, after the addition of thiourea in the working solution(Fig. 5). InthisTMRC, the zinc atom is coordinated with the sulfur atom of the thiourea, with a slight increase in system energy. 
M. A. Sozanskyi, V. E. Stadnik, P. Yo. Shapoval, O. P. Kurylo, R. R. Guminilovych

Modeled stages of $\mathrm{ZnS}$ and $\mathrm{ZnSe}$ films synthesis and energy stages diagrams

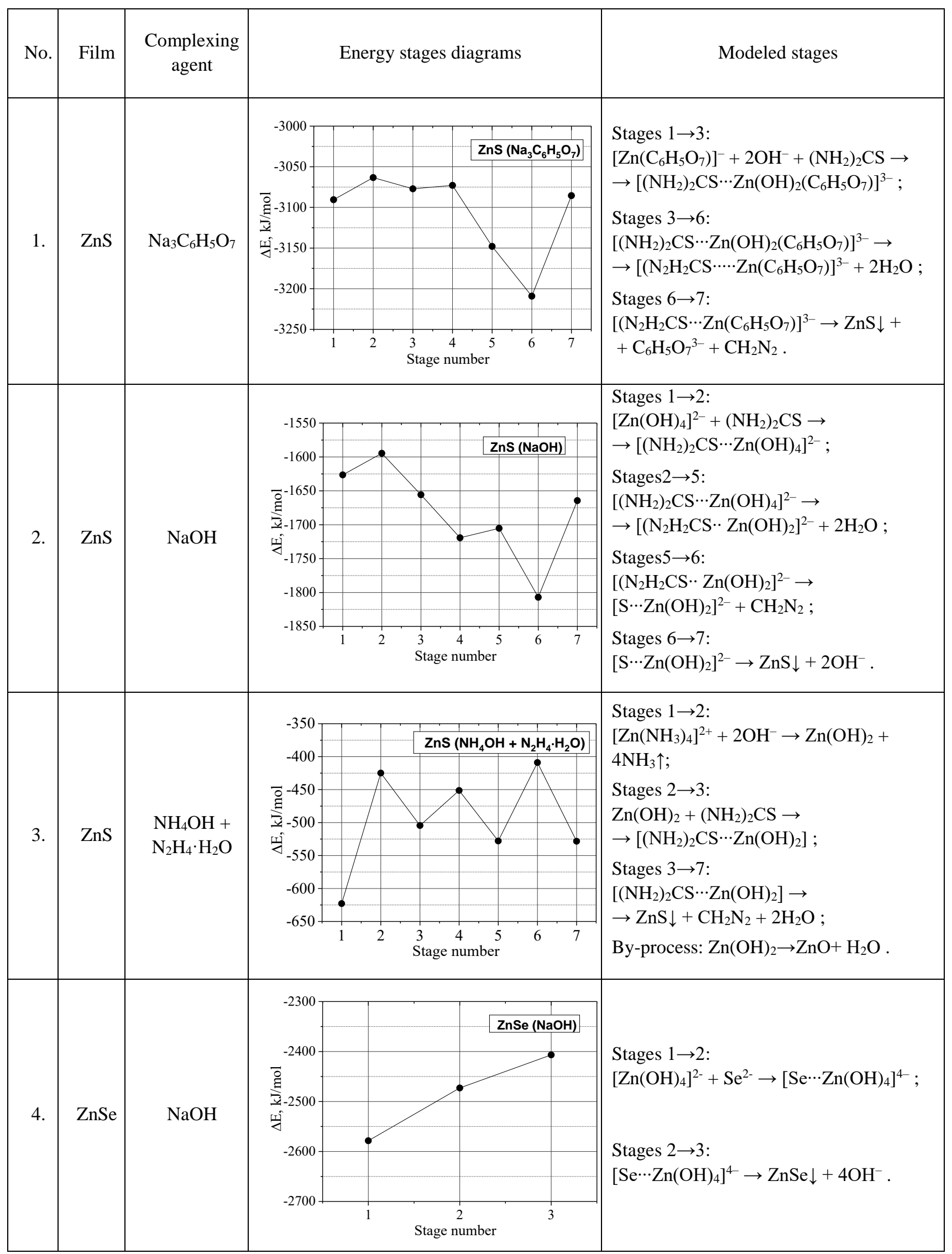


Quantum-chemical modeling of the chemistry process of the zinc sulfide and zinc selenide films synthesis

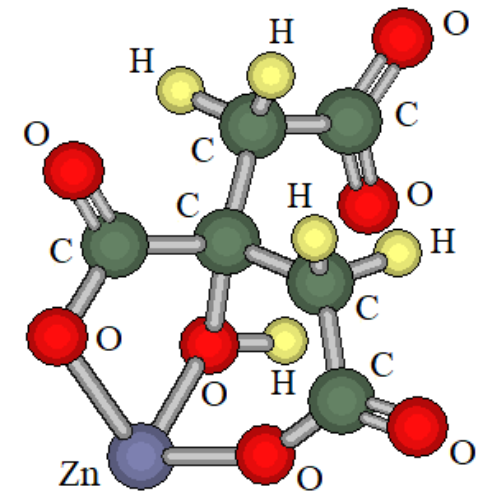

Fig. 1. The modeled $\left[\mathrm{Zn}\left(\mathrm{C}_{6} \mathrm{H}_{5} \mathrm{O}_{7}\right)\right]^{-}$ complex

At the next stages 2-5, transition states occur when the hydrogen atoms rearrange and transfer from thiocarbamide to tetrahydroxozincate. As a result, two water molecules (stages 3-5) are detached from the $\left[\left(\mathrm{NH}_{2}\right)_{2} \mathrm{CS} \cdots \mathrm{Zn}(\mathrm{OH})_{4}\right]^{2-} \mathrm{TMRC}$ with the appearance of a new $\left[\left(\mathrm{N}_{2} \mathrm{H}_{2} \mathrm{CS} \cdots \mathrm{Zn}(\mathrm{OH})_{2}\right]^{2-}\right.$ TMRC. The outcome of these stages is a decrease in the total energy of the system.

Further (stages 5-6), this intermediate complex decomposed with the formation of cyanamide and an intermediate phase - zinc dihydroxosulfide $\left[\mathrm{S} \cdots \mathrm{Zn}(\mathrm{OH})_{2}\right]^{2-}$, which is also accompanied by a decrease in the total energy of system.

At the last stages $6-7, \quad\left[\mathrm{~S} \cdots \mathrm{Zn}(\mathrm{OH})_{2}\right]^{2-}$ decomposes into insoluble zinc sulfide and two hydroxyl groups, and the stages themselves are the most energy-intensive.

Quantum-chemicalmodelingof $\mathrm{ZnS}$ synthesis

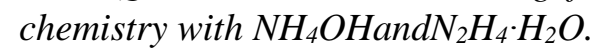

Zinc can form with complexing agents of $\mathrm{NH}_{4} \mathrm{OH}$ and $\mathrm{N}_{2} \mathrm{H}_{4} \cdot \mathrm{H}_{2} \mathrm{O}$ the water-soluble complexes of zinc tetraammonia $\left[\mathrm{Zn}\left(\mathrm{NH}_{3}\right)_{4}\right]^{2+}$ and zinc tetrahydrazine $\left[\mathrm{Zn}\left(\mathrm{N}_{2} \mathrm{H}_{4}\right)_{4}\right]^{2+}$, respectively.

Since, according to reference data [15], the value of stability constant for the zinc complex with ammonia $\left(\mathrm{pK}^{1-4}=9.08\right)$ is almost five orders higher than with hydrazine $\left(\mathrm{pK}^{1-4}=3.84\right)$, thenthe $\left[\mathrm{Zn}\left(\mathrm{NH}_{3}\right)_{4}\right]^{2+}$ complex form (Fig. 3) will be present in the working solution.

It can be seen from the modeling (table 1, no. 3, stages 1-2) that $\mathrm{ZnS}$ deposition is preceded by the stage of nucleation of the zinc hydroxide $\left(\mathrm{Zn}(\mathrm{OH})_{2}\right)$ phase.

With increasing system energy, the complex $\left[\mathrm{Zn}\left(\mathrm{NH}_{3}\right)_{4}\right]^{2+}$ decomposes to $\mathrm{Zn}(\mathrm{OH})_{2}$ and the ammonia as volatile compound evaporates from the working solution. This reduces the $\mathrm{NH}_{4} \mathrm{OH}$ concentration during the process of $\mathrm{ZnS}$ synthesis.

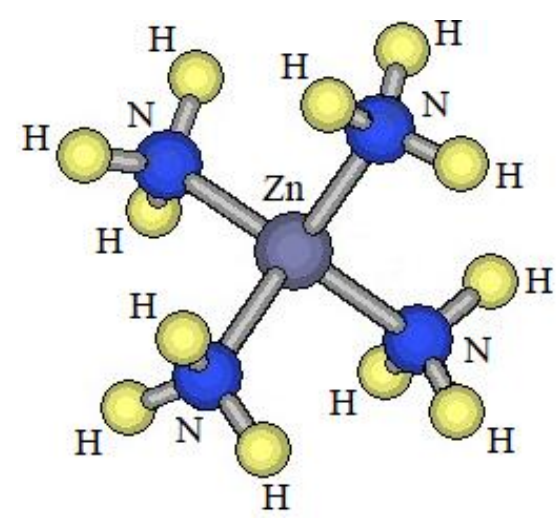

Fig. 3. The modeled $\left[\mathrm{Zn}\left(\mathrm{NH}_{3}\right)_{4}\right]^{2+}$ complex

As a consequence, the $\mathrm{pH}$ value decreases, which promotes the formation of zinc hydroxide. The decomposition of $\mathrm{Zn}(\mathrm{OH})_{2}$, during the passage of the main process, will probably lead to the appearance of the zinc oxide $(\mathrm{ZnO})$ phase as a by-product of the reaction. This may have happen at conditions, given in ref. [11]. The two water molecules are detach from $\mathrm{Zn}(\mathrm{OH})_{2}$ and it transforms to $\mathrm{ZnO}$ (table 1, no. 3,by-process).

In the subsequent stages, thiourea is combined with the newly formed $\mathrm{Zn}(\mathrm{OH})_{2}$ (stages 2-3). This produces the $\left[\left(\mathrm{NH}_{2}\right)_{2} \mathrm{CS} \cdots \mathrm{Zn}(\mathrm{OH})_{2}\right]$ TMRC (Fig. 6).

After that, during the further heating (stages 3-7) the intermediate complex undergoes to rearrangement of hydrogen atoms with detaching of water molecules and destruction into cyanamide molecules and insoluble $\mathrm{ZnS}$. Going to the last stage leads to a decrease in the total energy of the system, however, in the process of passing through the stages 3-7 there are local minimum and maximum of $\Delta \mathrm{E}$ energy change.

Quantum-chemicalmodelingof ZnSe synthesis chemistry with $\mathrm{NaOH}$.

Similarly to the synthesis of $\mathrm{ZnS}$ from a $\mathrm{NaOH}$ solution, in the case of $\mathrm{ZnSe}$ formation from hydroxide system, a soluble tetrahydroxy zincate $\left[\mathrm{Zn}(\mathrm{OH})_{4}\right]^{2-}$ complex will form. Itsgeometry areillustrated inFig. 3. The difference in this process will be the different nature of the chalcogenizing reagent, namely the generated $\mathrm{Se}^{2-}$ ions from elemental powdered selenium.

The results of quantum chemical modeling (table 1, no. 4, stages 1-2) indicate that at the beginning of the deposition, selenium ion is coordinated with the zinc atom of tetrahydroxy zincate forming the $\left[\mathrm{Se} \cdots \mathrm{Zn}(\mathrm{OH})_{4}\right]^{4}$ TMRC (Fig. 7). This process requires the supply of energy to the system. 


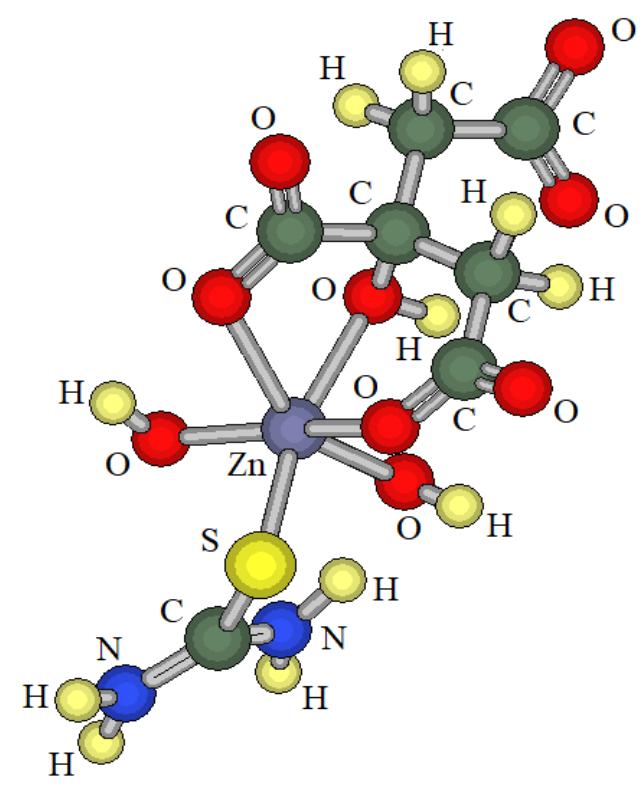

Fig. 4. The modeled $\left[\left(\mathrm{NH}_{2}\right)_{2} \mathrm{CS} \cdots \mathrm{Zn}(\mathrm{OH})_{2}\left(\mathrm{C}_{6} \mathrm{H}_{5} \mathrm{O}_{7}\right)\right]^{3-} \mathrm{TMRC}$

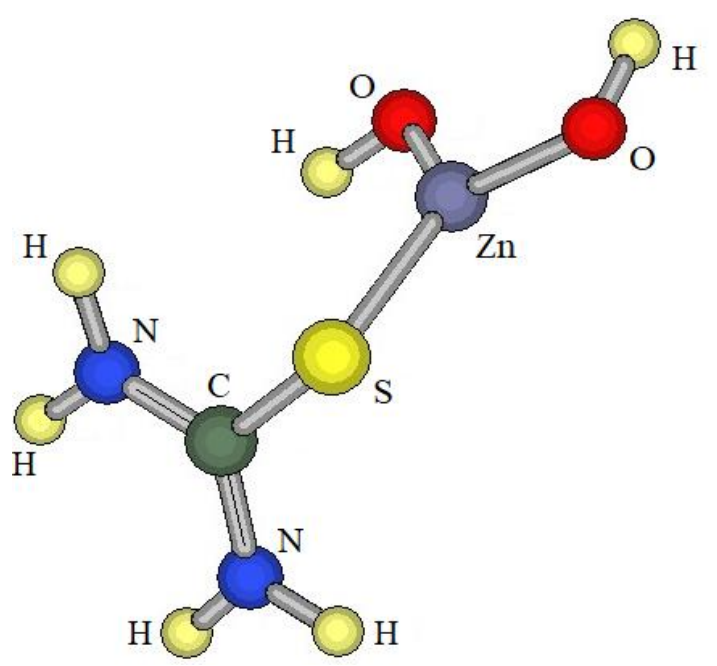

Fig. 6. The modeled $\left[\left(\mathrm{NH}_{2}\right)_{2} \mathrm{CS} \cdots \mathrm{Zn}(\mathrm{OH})_{2}\right] \mathrm{TMRC}$

Upon further heating of the reaction mixture (steps 2-3), the intermediate complex decomposed with the formation of insoluble zinc selenide and four hydroxide groups.

It is worth noting that in the case of obtaining the results of quantum-chemical calculations by the semiempirical PM7 method, their accuracy for the $\mathrm{ZnSe}$ formation process decreases, unlike for $\mathrm{ZnS}$ films, since the quantitative content of lighter atoms $(\mathrm{H}, \mathrm{C}, \mathrm{O}, \mathrm{N}, \mathrm{S})$ in the modeled system decreases and the heavier ones $(\mathrm{Zn}, \mathrm{Se})$ grows. This increases the number of approximations performed in the calculations by semiempirical method [16].

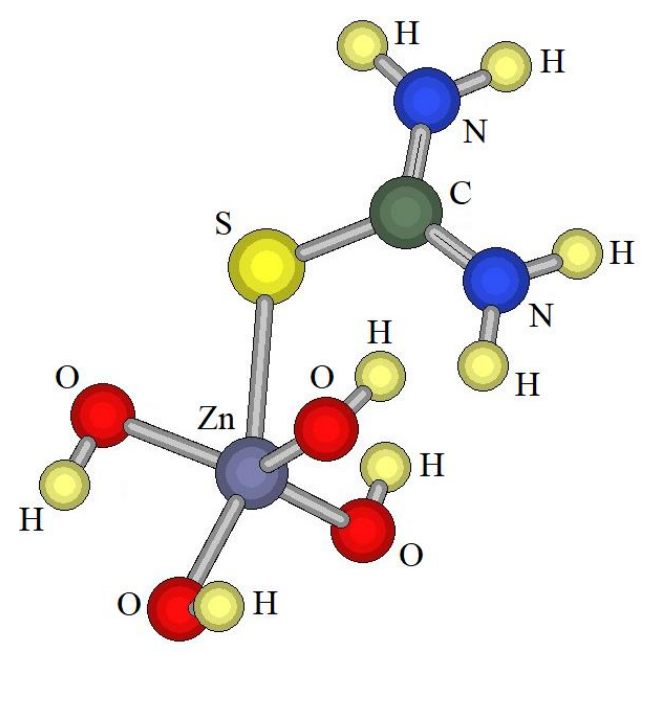

Fig. 5. The modeled $\left[\left(\mathrm{NH}_{2}\right)_{2} \mathrm{CS} \cdots \mathrm{Zn}(\mathrm{OH})_{4}\right]^{2-} \mathrm{TMRC}$

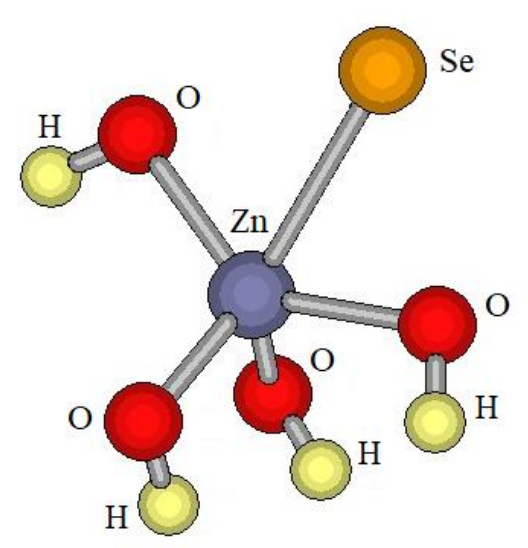

Fig. 7. The modeled $\Pi \mathrm{P} 3 \mathrm{~K}\left[\mathrm{Se} \cdot \mathrm{Zn}(\mathrm{OH})_{4}\right]^{4-} \mathrm{TMRC}$

According to quantum calculations (table 1), in all cases of $\mathrm{ZnS}$ and $\mathrm{ZnSe}$ synthesis, it is necessary to provide energy to start the initial stages and pass the energy barrier (the plot that connects the first two points on the energy diagrams). It reaches the highest value for $\mathrm{ZnS}$ synthesis with the use of $\mathrm{NH}_{4} \mathrm{OH}$ and $\mathrm{N}_{2} \mathrm{H}_{4} \cdot \mathrm{H}_{2} \mathrm{O}$ complexing agents $(197 \mathrm{~kJ} / \mathrm{mol})$. It is somewhat smaller for the $\mathrm{ZnSe}$ synthesis $(105.6 \mathrm{~kJ} / \mathrm{mol})$ and the smallest for $\mathrm{ZnS}$ synthesis with the use of $\mathrm{NaOH}$ and $\mathrm{Na}_{3} \mathrm{C}_{6} \mathrm{H}_{5} \mathrm{O}_{7}$ (31.8 and $27.2 \mathrm{~kJ} / \mathrm{mol}$, respectively).

To verify the results of quantum-chemical modeling of $\mathrm{ZnS}$ and $\mathrm{ZnSe}$ obtaining, the $\mathrm{ZnS}$ and 


\section{Quantum-chemical modeling of the chemistry process of the zinc sulfide and zinc selenide films synthesis}

ZnSe films were synthesized experimentally under modeled conditions. Their X-ray phase analysis was performed (figs. 8,9). It has been established that coatings contain the corresponding phases of cubic (sphalerite-type) modification. In all cases, the films were single-phase, except for the $\mathrm{ZnS}$ films synthesis with the use of ammonium hydroxide with hydrazine hydrate. Such samples containedtwo phases $\mathrm{ZnO}$ and $\mathrm{ZnS}$, which was predicted by modeling ofthecorresponding case.

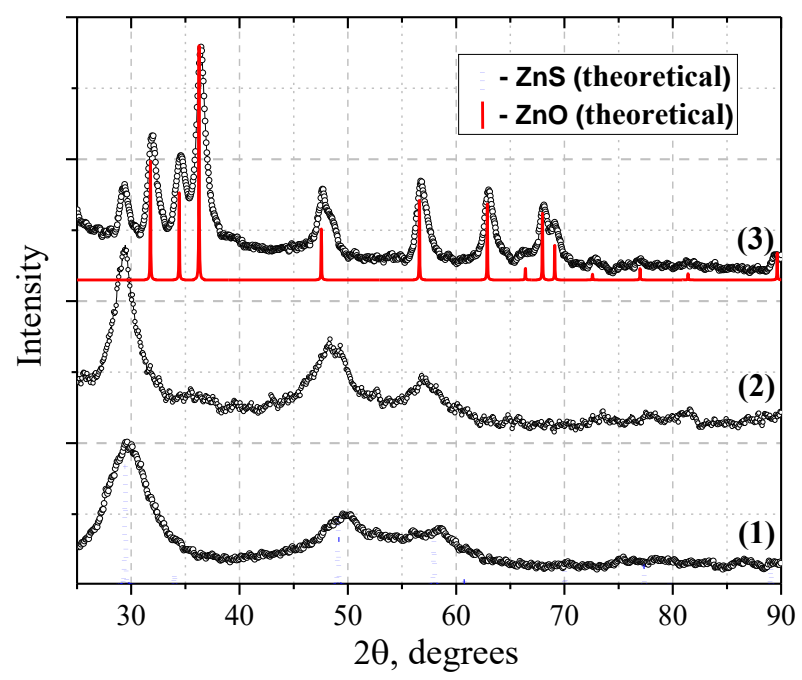

Fig. 8. The XRD patterns of ZnS films, obtained with the use of $\mathrm{Na}_{3} \mathrm{C}_{6} \mathrm{H}_{5} \mathrm{O}_{7}(1), \mathrm{NaOH}(2)$, $\mathrm{NH}_{4} \mathrm{OH}+\mathrm{N}_{2} \mathrm{H}_{4} \cdot \mathrm{H}_{2} \mathrm{O}(3)$ and thetheoretical diffraction patterns of $\mathrm{ZnS} i \mathrm{ZnO}$

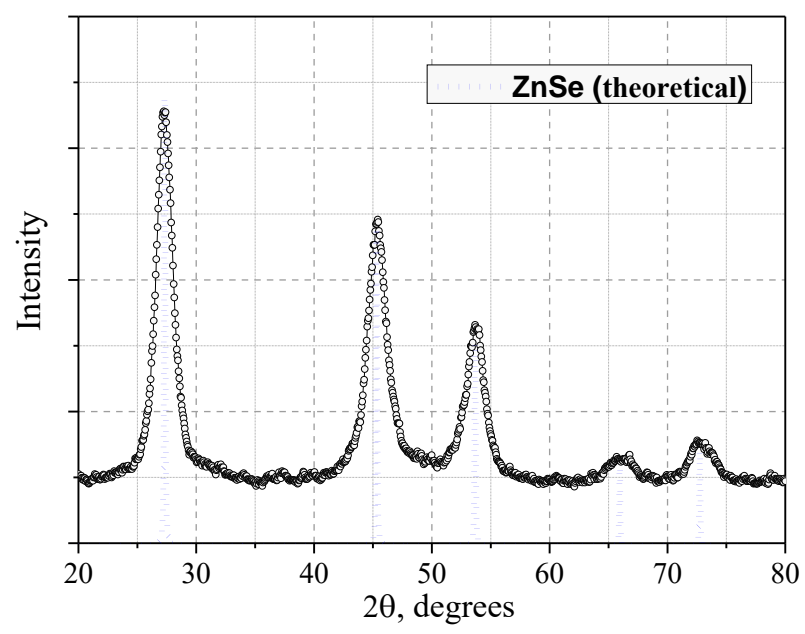

Fig. 9. The XRD pattern of ZnSe film, obtained with the use of $\mathrm{NaOH}$ the theoretical diffraction patterns of $\mathrm{ZnSe}$

\section{Conclusions}

From the performed simulations and calculations for the four cases of zinc chalcogenides formation, the $\mathrm{NaOH}$ complexing agent behaves energetically more profitably during the $\mathrm{ZnS}$ synthesis in the aggregate of all stages of synthesis reactions. However, according to the studies described in [17], it was established that when $\mathrm{NaOH}$ was used, the surface of the synthesized films consisted of spherical particles. Their contact area with the substrate surface is small.This results in weak adhesion to glass substrates and the $\mathrm{ZnS}$ layer could be removed by applying mechanical forces to the coating. Also, during prolonged synthesis, the upper film layer of $\mathrm{ZnS}$ spherical particles was partially washed out at cleaning of its surface by a jet of distilled water.

The $\mathrm{ZnS}$ formation reaction with the use of $\mathrm{Na}_{3} \mathrm{C}_{6} \mathrm{H}_{5} \mathrm{O}_{7}$ complexing agent is less energy profitable. However, the obtained $\mathrm{ZnS}$ coatings were characterized by a solid, smooth and mirror surface with good adhesion to glass substrates [11, 18]. With the increase in deposition duration, there was observed a linear region of increase in the films thickness with uniform growth over the entire substrate surface. The formation of spherical particles was not found, but only a small amount of surface defects. The $\mathrm{ZnS}$ contact area with the substrate is large, which explains the good adhesion. After depletion of the working solution, the number of conglomerates on the film surface increases and it begins cracking.

In the case of the use of $\mathrm{NH}_{4} \mathrm{OH}$ and $\mathrm{N}_{2} \mathrm{H}_{4} \cdot \mathrm{H}_{2} \mathrm{O}$ complexing agents, the zinc sulfide synthesis characterized by a tendency to form byproducts $[11,19]$ and the deposition process itself is more energy-intensive than with the other complexing agents. This makes it impossible to use $\mathrm{NH}_{4} \mathrm{OH}$ and $\mathrm{N}_{2} \mathrm{H}_{4} \cdot \mathrm{H}_{2} \mathrm{O}$ for the production of film elements based on $\mathrm{ZnS}$ and $\mathrm{ZnSe}$. The obtained sulfide films under similar conditions with another element of the zinc subgroup - cadmium did notcontain by-products [20, 21].

The $\mathrm{ZnSe}$ synthesis requiresmore energy for it formation than the synthesis of $\mathrm{ZnS}$. This can be explained by a different nature of the chalcogenizing agent, which was used to obtain zinc selenide $\left(\mathrm{Se}^{2-}\right.$ ions are negatively charged instead of electroneutral $\left.\left(\mathrm{NH}_{2}\right)_{2} \mathrm{CS}\right)$. As a consequence, there is a need to overcome the repulsion between $\mathrm{Se}^{2-}$ and $\mathrm{OH}^{-}$ions. 
The synthesis of $\mathrm{ZnS}$ films was performed with the use of trisodium citrate, sodium hydroxide and a pair of ammonium hydroxide-hydrazine hydrate. For the $\mathrm{ZnSe}$ films synthesis only sodium hydroxide was used. The X-ray analysis confirmed the $\mathrm{ZnS}$ formation, as well as the $\mathrm{ZnO}$ formation duringthe synthesis of $\mathrm{ZnS}$ films withthe useof $\mathrm{NH}_{4} \mathrm{OH}$ and $\mathrm{N}_{2} \mathrm{H}_{4} \cdot \mathrm{H}_{2} \mathrm{O}$, which was predicted by the correspondingquantum-chemical modeling.

\section{References}

1. Thiel, W. (2014). Semiempirical quantum-chemical methods. WIREs Computational Molecular Science, 4(2), 145-157. doi:10.1002/wcms.1161

2. Bertoli, A. C., Carvalho, R., Freitas, M. P., Ramalho, T. C., Mancini, D. T., Oliveira, M. C., Varennes A., \& Dias, A. (2015). Theoretical and experimental investigation of complex structures citrate of zinc (II). Inorganica Chimica Acta, 425, 164-168. doi: 10.1016/j.ica.2014.10.025

3. Bertoli, A. C., Carvalho, R., Freitas, M. P., Ramalho, T. C., Mancini, D. T., Oliveira, M. C., Varennes A., \& Dias, A. (2015). Theoretical spectroscopic studies and identification of metal-citrate $(\mathrm{Cd}$ and $\mathrm{Pb})$ complexes by ESI-MS in aqueous solution. Spectrochimica Acta Part A: Molecular and Biomolecular Spectroscopy, 137, 271280. doi: 10.1016/j.saa.2014.08.053

4. Markov, V., Maskayeva, L., \& Ivanov, P. (2006). Gidrokhimicheskoye osazhdeniye plenok sulfidov metallov: modelirovaniye i yeksperiment. Yekaterinburg: UrO RAN.

5. Berg, L., Meshchenko, K., \& Bogomolov, YU. (1970). Vybor optimal'nykh usloviy osazhdeniya plenok sul'fida svintsa. Neorganicheskiye materialy, 6(7), 1337-1338.

6. Markov, V, \& Maskayeva, L. (2005). Raschet usloviy obrazovaniya tverdoy fazy khal'kogenidov metallov pri gidrokhimicheskom osazhdenii. Yekaterinburg: GOU VPO UGTU-UPI.

7. Jalilehvand, F., Amini, Z., \& Parmar, K. (2012). Cadmium(II) Complex Formation with Selenourea and Thiourea in Solution: An XAS and 113Cd NMR Study. Inorganic Chemistry, 51(20), 10619-10630. doi:10.1021/ic300852t

8. Bochkarev, V., Soroka, L., Klimova, T., \& Velikorechina, L. (2015). Modeling of Condensation Reaction of Aniline to Diphenylamine by PM7 Method. Procedia Chemistry, 15, 320-325. doi:10.1016/j.proche.2015.10.051

9. Stewart, J. (2012). MOPAC2012 Home Page. Retrieved from http://openmopac.net/MOPAC2012.html

10. Senda, N. (2018). Winmostar - Structure modeler and visualizer for free Chemistry simulations. Retrieved from https://winmostar.com/
11. Shapoval, P., Sozanskyi, M., Yatchyshyn, I., Kulyk, B., Shpotyuk, M., \& Gladyshevskii, R. (2016). The Effect of Different Complexing Agents on the Properties of Zinc Sulfide Thin Films Deposited from Aqueous Solutions. Chemistry \& Chemical Technology, 10(3), 317323. doi: $10.23939 /$ chcht10.03.317

12. Sozans'kyy, M., Shapoval, P., Chaykivs'ka, R., Stadnik, V., \& Yatchyshyn, Y. (2016). Hidrokhimichnyy syntez tonkykh plivok tsynku selenidu (ZnSe) v prysutnosti natriyu hidroksydu ta yikhni vlastyvosti. Visnyk Natsional'noho universytetu "L'vivs'ka politekhnika". Seriya: Khimiya, tekhnolohiya rechovyn ta yikh zastosuvannya, 841, 36-42.

13. Sozanskyi, M., Chaykivska, R., Shapoval, P., Yatchyshyn, I., \&Vytrykush, N. (2018). Influence of deposition duration on properties of $\mathrm{ZnSe}$ and $\mathrm{ZnSxSe1-x}$ films. Visnyk of the Lviv University. Series Chemistry, 59(1), 131. doi: 10.30970/vch.5901.131

14. Kraus, W., \& Nolze, G. (1996). POWDER CELL - a program for the representation and manipulation of crystal structures and calculation of the resulting X-ray powder patterns. Journal of Applied Crystallography, 29(3), 301-303. doi:10.1107/s0021889895014920

15. Lur'ê, YU. YU. (1989). Spravochnik po analiticheskoy khimii. Moskva: Khimiya.

16. Accuracy of PM7. (2012). Retrieved from http://openmopac.net/PM7_accuracy/PM7_accuracy.html

17. Shapoval, P., Sozans'kyy, M., \& Yatchyshyn, Y. (2015). Syntez I vlastyvosti plivok tsynksul'fidu (ZnS), otrymanykh $\mathrm{z}$ vykorystannyam kompleksoutvoryuvacha natriyhidroksydu. Visnyk Natsional'noho Universytetu "L'vivs'ka Politekhnika". Seriya: Khimiya, tekhnolohiya rechovyn ta yikh zastosuvannya, 812, 43-47.

18. Sozanskyi, M., Shapoval, P., Yatchyshyn, I., Stadnik, V., \& Gladyshevskii, R. (2015). Synthesis of ZnS thin films from aqueous caustic of trisodium citrate and their properties. Odes'Kyi Politechnichnyi Universytet. Pratsi, (3), 71-75. doi: 10.15276/opu.3.47.2015.17

19. Shapoval, P., Sozans'kyy, M., Yatchyshyn, Y. \& Huminilovych R. (2014). Syntez plivok tsynk sul'fidu (ZnS) metodom khimichnoho poverkhnevoho osadzhennya. Visnyk Natsional'noho universytetu 'L'vivs'ka politekhnika". Seriya: Khimiya, tekhnolohiya rechovyn ta yikh zastosuvannya, 787, 31-35.

20. Lo, Y., Choubey, R., Yu, W., Hsu, W., \& Lan, C. (2011). Shallow bath chemical deposition of CdS thin film. Thin Solid Films, 520(1), 217-223. doi: 10.1016/j.tsf.2011.07.035

21. Reddy, M. (2013). Properties of CdS Chemically Deposited thin films on the Effect of Ammonia Concentration. IOSR Journal of Applied Physics, 4(4), 01-07. doi: 10.9790/4861-0440107 
Quantum-chemical modeling of the chemistry process of the zinc sulfide and zinc selenide films synthesis

М. А. Созанський, В. Є. Стаднік, П. Й. Шаповал, О. П. Курило, Р. Р. Гумінілович

Національний університет “Львівськаполітехніка", кафедра фізичної, аналітичної та загальної хімії

\section{КВАНТОВО-ХІМІЧНЕ МОДЕЛЮВАННЯ ХІМІЗМУ ПРОЦЕСУ СИНТЕЗУ ПЛІВОК ЦИНКУ СУЛЬФІДУ ТА ЦИНКУ СЕЛЕНІДУ}

Проведено квантово-хімічне моделювання процесу синтезу ZnS та ZnSe у водних розчинах. Змодельовано синтез $\mathrm{ZnS}$ утворенням проміжних комплексних форм Zn(II) з тринатрій цитратом, натрій гідроксидом та парою амоній гідроксиду 3 гідразин гідратом. Під час синтезу ZnSe використано лише натрій гідроксид. Встановлено, що цей процес проходить через декілька проміжних стадій з утворенням перехідних реакційноздатних комплексів. На основі отриманих даних побудовано енергетичні діаграми стадій та здійснено порівняння процесів синтезу $\mathrm{ZnS}$ i $\mathrm{ZnSe} 3$ різними комплексоутворювальними реагентами. Методом хімічного синтезу отримано плівки $\mathrm{ZnS}$ та ZnSe 3 водного розчину солі цинку, комплексоутворювального та халькогенізуючого реагентів. Рентгенофазовим аналізом підтверджено утворення цільових сполук, а також формування ZnO під час синтеуі плівок $\mathrm{ZnS}$ з використанням амоній гідроксиду і гідразин гідрату.

Ключові слова: цинк сульфід, цинк селенід, тонкі плівки, квантово-хімічне моделювання, напівемпіричні методи, напівпровідники. 